\title{
Sequence analysis of the CXCR4 gene derived from cells surviving feline lentivirus infection.
}

\section{$\operatorname{AUTHOR}(\mathrm{S})$ :}

Tochikura, Tadafumi S; Morimoto, Kinjiro

\section{CITATION:}

Tochikura, Tadafumi S ... [et al]. Sequence analysis of the CXCR4 gene derived from cells surviving feline lentivirus infection.. Archives of virology 2014, 159(6): 1511-1513

\section{ISSUE DATE:}

2014-06

URL:

http://hdl.handle.net/2433/199622

\section{RIGHT:}

The final publication is available at Springer via http://dx.doi.org/10.1007/s00705-0131960-8.; This is not the published version. Please cite only the published version.; この論 文は出版社版でありません。引用の際には出版社版をご確認ご利用ください。 
Sequence analysis of CXCR4 gene derived from feline lentivirus surviving cells

Tadafumi S Tochikura $^{\text {a*}}$, Kinjiro Morimoto ${ }^{b}$

anstitute of Laboratory Animals, Graduate School and Faculty of Pharmaceutical

Sciences, Kyoto University, Sakyo-ku, Kyoto 606-8501, Japan

${ }^{\mathrm{b}}$ Faculty of Pharmacy, Yasuda Women's University, Asaminami-ku, Hiroshima 731-0153, Japan

* Correspondence to :

Tadafumi S.Tochikura

Institute of Laboratory Animals

Graduate School and Faculty of Pharmaceutical Sciences

Kyoto University, Sakyo-ku, Kyoto 606-8501, Japan

TEL : +81-75-753-4564

FAX : +81-75-761-2698

E-mail address : tstochikura@yahoo.co.jp 


\section{Abstract}

The feline 3201-S cell line was established from cells that survived productive infection with feline immunodeficiency virus (FIV). We have recently shown that 3201-S cells are free of FIV DNA, and are refractory to FIV reinfection. In addition, while the cells express CXCR4, a co-receptor for FIV infection, they are unresponsive to the CXCR4 ligand. The present study reports that 3201-S cells encode distinct mutations in the CXCR4 gene. It would appear that 3201 cells are likely to be heterogeneous, consisting of phenotypically diverse mixed populations resulting from genetic mutation, suggesting that this defect can render the CXCR4 receptor expressed in 3201-S cells biologically dysfunctional.

Keywords : Feline immunodeficiency virus , 3201 , 3201-S , CXCR4 , Sequence analysis 
Feline immunodeficiency virus (FIV) is a lentivirus associated with immunosuppressive disease in cats. It is similar to human immunodeficiency virus type 1 (HIV-1), although the viruses are genetically distinct [1,2]. Like HIV-1, FIV utilizes CXCR4, a member of the chemokine group of G-protein-coupled receptor family, as virus-entry co-receptor for infection. There is evidence of shared chemokine receptor use between HIV-1 and FIV [3]. CXCR4 is a seven transmembrane protein with an extracellular N-terminus, three extracellular loops (ECLs), three intracellular loops (ICLs) and an intracellular C-terminal tail [4]. Although the second extracellular loop (ECL2) has been reported to determine its function as a co-receptor for FIV [5], details of the mechanism of FIV entry in to cells remain to be elucidated,

In previous studies, we found that the feline thymic lymphoma 3201 cell line [6] was highly susceptible to the cytopathic effects of cell culture-adapted Petaluma strain of FIV [7]. However, after a productive infection associated with extensive cell killing, a few surviving cell populations remained. The surviving cells, designated as 3201-S, were shown to harbor no viral DNA as a proviral state [8]. We found that both 3201 and 3201-S cells express CXCR4, although the parental uninfected 3201 cells could be distinguished from 3201-S cells, as the 3201 cells seem to express much higher levels of CXCR4, as observed by fluorescence intensity. Of particular interest is the fact that 3201-S cells were unable to support the viral replicative cycle after reinfection with FIV. The presence of reverse-transcribed FIV DNA in the FIV-reinfected 3201-S cells early postinfection, albeit at an extremely low frequency, suggests that 3201-S cells are 
insignificantly reinfectable by FIV as revealed by the real-time quantitative PCR analysis using extracted DNA from the cells, however, FIV failed to spread in 3201-S cells as demonstrated by the lack of any persistent presence of viral DNA. Furthermore, the stromal cell - derived factor $1 \alpha$ (SDF-1 $\alpha$ ) stimulates calcium mobilization in 3201 but not in 3201-S cells, suggesting that the receptor is not functional in 3201-S cells [8]. These findings led us to hypothesize that phenotypic heterogeneity exists in the original 3201 cells and their heterogenous expression of CXCR4 may influence CXCR4-dependent FIV entry and responsiveness to SDF-1a. This brief report describes a study of sequence analysis of CXCR4 gene which we carried out to better understand the nature of CXCR4 dysfunction in 32015 cells, and their resistance to sustained FIV infection.

In order to determine the cause of the functional difference of CXCR4, the nucleotide sequences coding for CXCR4 in the two 3201-derived cell lines were examined. Total RNA was extracted from cultured 3201 and 3201-S cells using RealTime ready Cell Lysis Kit (Roche Diagnostics Japan, Tokyo). The RNA was reverse transcribed using Transcriptor Universal cDNA Master (Roche Diagnostics Japan, Tokyo) according to the manufacturer's instructions. Polymerase chain reaction (PCR) was performed using Pyrobest DNA polymerase (Takara Bio Inc, Otsu, Japan) and specific oligonucleotide primers for CXCR4; a sense primer ACCATGGACGGGTTTCGTATATAC (ATG corresponding to the start codon of the gene) and an antisense primer TTAGCTGGAGTGAAAACTTGAAGA (TTA being complementary to the stop 
codon of the gene), producing 1065 bases long cDNA. The PCR products were subjected to DNA sequence analysis. The DNA sequencing was performed using BigDye terminator cycle sequencing kit, and analyzed with ABI PRISM 310 Genetic Analyzer (Applied Biosystems Japan, Tokyo).

The nucleotide sequences coding for CXCR4 in the two 3201-derived cell lines showed a 15 bp deletion in the CXCR4 genes in both cell types [3], in comparison with a published sequence (GenBank accession \# U67558). The deletion spanned amino acid residues 227 to 231 in a region corresponding to ICL3, which is associated with the domain required for Gi-dependent signaling [4] (Fig. 1). Since 3201 cells showed a flux of $\mathrm{Ca}^{2+}$ in response to SDF-1 $\alpha$ and susceptibility to FIV infection [8], the residues Leu-Ser-His-Ser-Lys do not appear to be essential for the biological function of the CXCR4 protein.

More importantly, insertion of a thymidine base within the ECL3 region at the position between nucleotides 831 and 832 in the CXCR4 gene of 3201-S cells has been noted. This insertion causes a nonsense frame shift leading to an early stop codon at AA position and thus truncation of the CXCR4 receptor (Fig. 2). A predicted histidine residue (position 277) in 3201 cells was replaced by an alanine residue in 3201-S cells, resulting in a putatively truncated protein of 277 amino acids, whereas CXCR4 from parental 3201 cells encoded a protein of 348 amino acids (Fig. 1). Although ECL2 is the principle determinant of co-receptor function, for 
HIV-1 [9], and FIV [5], the adjacent loops such as ECL1 and ECL3 may help keep the ECL2 in the appropriate conformation for CXCR4 to support viral entry.

Our earlier observation that 3201-S cells can be re-infected by FIV, although inefficiently, but that the virus is unable to maintain the proviral state in these cells [8] is interesting in light of herein presented results. Our findings suggest that the truncated form of the CXCR4 protein (frame shift-induced deletion of the last 71 amino acids) may still exhibit conformational structures required for FIV entry, even though this mutated CXCR4 is very weakly expressed at the surface of the cells. In contrast, the truncated CXCR4 seems to have lost its function as chemokine receptor, since 3201-S cells did not respond to SDF-1a. This finding is indicative for the coreceptor function of CXCR4 being independent of its function in chemokine signaling. This is in agreement with a previous report [10].

It remains unclear whether the mutated CXCR4 is the only reason for the FIV resistance in the 3201-S cells. It is necessary to study whether the exogenous expression of CXCR4 after transfecting the parental 3201 CXCR4 into the 3201-S cells can render the cells susceptible to FIV infection.

To our knowledge, this is the first report on non-synonymous mutations within the CXCR4 gene of 3201-S cells. These mutations affect the third extracellular loop and negatively affect the chemokine receptor function of CXCR4. It appears that 3201 are genetically heterogeneous cells, as they are constituted of a mixed population of cells expressing 
biologically functional and mutation-induced dysfunctional CXCR4 receptors.

These findings provide new insights into the natural history of FIV infection, and may be useful in the development of new prophylaxis strategies against FIV infection.

\section{Acknowledgements}

We are grateful to Dr.Lawrence E. Mathes for providing the 3201 cell line. We also wish to thank Dr.Nobuyuki Itoh and Dr.Hideo Saji for their constant support and encouragement, and Dr. Nancy Long Sieber for critically reviewing the manuscript and helpful discussions.

\section{References}

1. Pedersen NC, Ho E, Brown ML, Yamamoto JK (1987) Isolation of a T-lymphotropic virus from domestic cats with an immunodeficiency-like syndrome. Science 235(4790):790-793

2. Olmsted RA, Hirsch VM, Purcell RH, Johnson PR (1989) Nucleotide sequence analysis of feline immunodeficiency virus : genome organization and relationship to other lentiviruses. Proc Natl Acad Sci USA 86(20) : 8088-8092 
3. Willett BJ, Picard L, Hosie MJ, Turner JD, Adema K, Clapham PR (1997) Shared usage of the chemokine receptor CXCR4 by the feline and human immunodeficiency viruses. J Virol 71(9):6407-6415

4. Juarez J, Bendall L, Bradstock K (2004) Chemokines and their receptors as therapeutic targets : the role of the SDF-1/CXCR4 axis. Curr Pharm Des 10(11):1245-1259

5. Willett BJ, Adema K, Heveker N, Brelot A, Picard L, Alizon M, Turner JD, Hoxie JA, Peiper S, Neil JC, Hosie MJ (1998) The second extracellular loop of CXCR4 determines its function as a receptor for feline immunodeficiency virus. J Virol 72(8):6475-6481

6. Snyder HW Jr, Hardy WD Jr, Zuckerman EE, Fleissner E (1978) Characterisation of a tumor-specific antigen on the surface of feline lymphosarcoma cells. Nature 275(5681) : $656-658$

7. Tochikura TS, Hayes KA, Cheney CM, Tanabe-Tochikura A, Rojko JL, Mathes LE, Olsen RG (1990) In vitro replication and cytopathogenicity of the feline immunodeficiency virus for feline T4 thymic lymphoma 3201 cells. Virology 179(1): 492-497 
8. Tochikura TS, Motokawa K, Naito Y Kozutsumi Y, Tanabe-Tochikura A, Hohdatsu T(2010) Differential CXCR4 expression and function in subpopulations of the feline lymphoma cell line 3201 susceptible to feline immunodeficiency virus. J Feline Med Surg 12(4):269-277

9. Brelot A, Heveker N, Adema K, Hosie MJ, Willett B, Alizon M (1999) Effect of mutations in the second extracellular loop of CXCR4 on its utilization by human and feline immunodeficiency viruses. J Virol 73(4):2576-2586

10. Doranz BJ, Orsini MJ, Turner JD, Hoffman TL, Berson JF, Hoxie JA, Peiper SC, Brass LF, Doms RW (1999) Identification of CXCR4 domains that support coreceptor and chemokine receptor functions. J Virol 73(4):2752-2761

\section{Figure Legends}

Figure 1. Comparison of the predicted amino acid sequences of feline CXCR4 in

3201 and 3201-S cells. Numbers indicate the position of the amino acid. The character . denotes an identical amino acid, and - denotes the residue that has been deleted.

ICL3, intracellular loop 3 ; ECL3, extracellular loop 3. 
Figure 2. CXCR4 mutation by polymerase chain reaction and direct DNA

sequencing. The sequence difference is caused by a T addition in 3201-S cells, which generates a mutated amino acid sequence causing a STOP. 
CXCR4-aa 1:MDGFRIYPSDNYTEDDLGSGDYDSMKEPCFREENAHFNRIFLPTVYSIIFLTGIVGNGLV 60

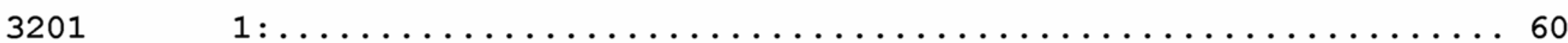

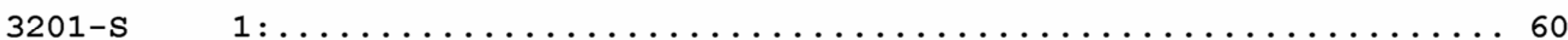

CXCR4-aa 61 : ILVMGYQKKLRSMTDKYRLHLSVADLLFVLTLPFWAVDAVANWYFGKFLCKAVHVIYTVN 120

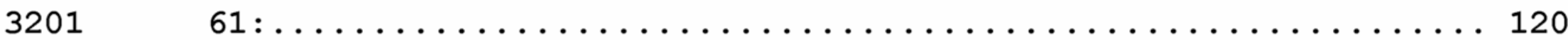

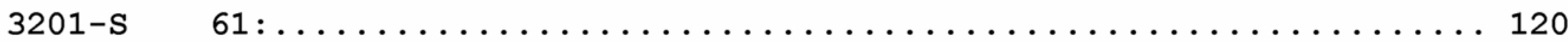

CXCR4-aa 121 : LYSSVLILAFISLDRYLAIVHATNSQRPRKLLAEKVVYVGVWIPALLLTIPDFIFANVRE 180

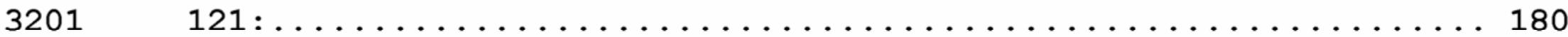

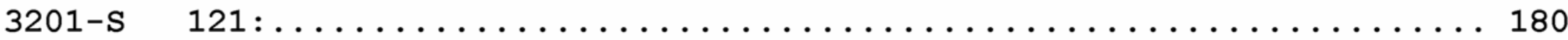

CXCR4-aa 181 :ADGRYICDRFYPSDSWLVVFQFQHIMVGLILPGIVILSCYCIIISKLSHSKGYQKRKALK 240

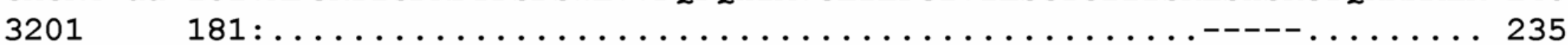

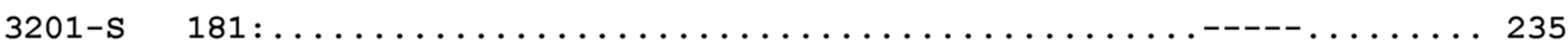

ECL3

CXCR4-aa 241:TTVILILAFFACWLPYYIGISIDSFILLEIIKQGCEFESTVHKWISITEALAFFHCCLNP 300

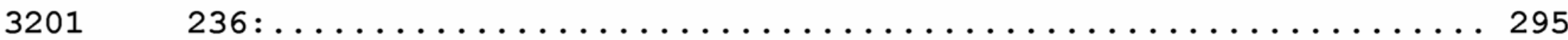

3201-S $\quad 236: \ldots \ldots \ldots \ldots \ldots \ldots \ldots \ldots \ldots \ldots \ldots \ldots \ldots \ldots$

CXCR4-aа 301 : ILYAFLGAKFKTSAQHALTSVSRGSSLKILSKGKRGGHSSVSTESESSSFHSS 353

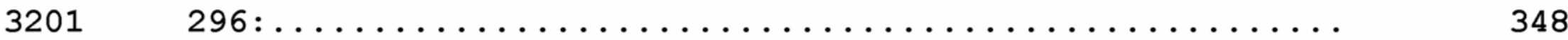

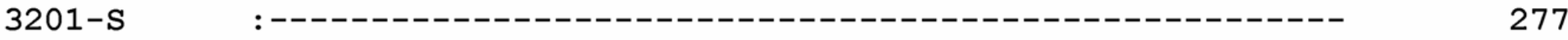

Figure 1. 


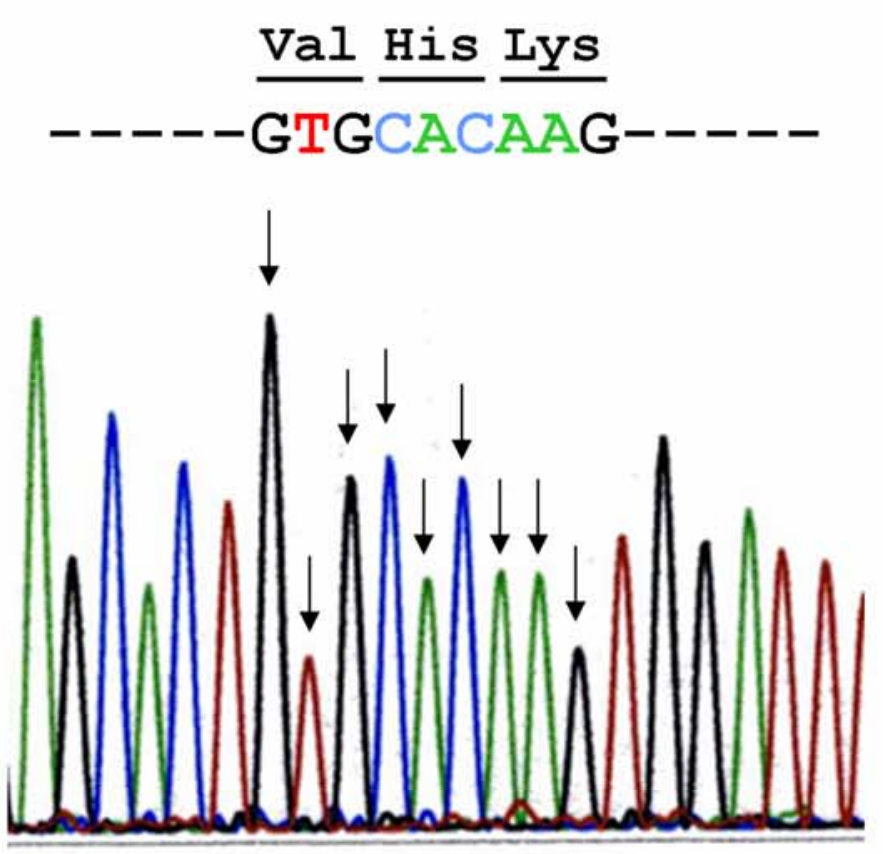

3201

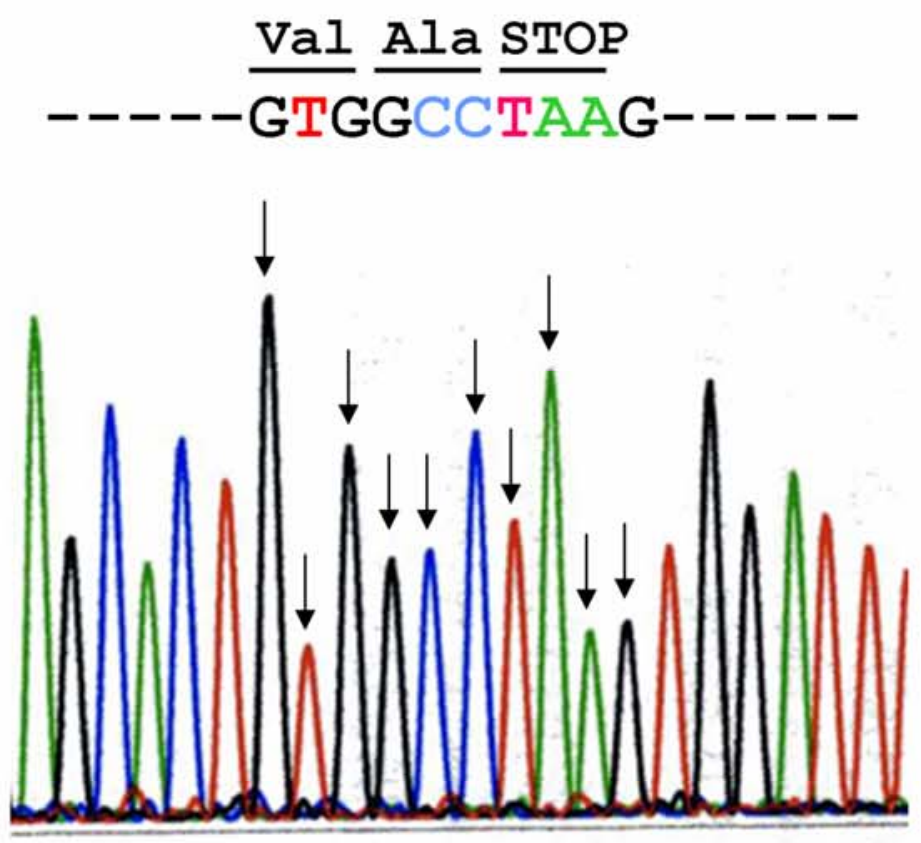

3201-S

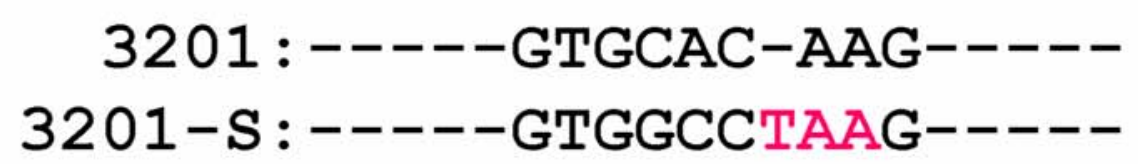

Figure 2. 